\title{
The Determinants of Employee Performance
}

\author{
Jhon Veri ${ }^{1}$ \\ University of Putra Indonesia YPTK Padang, Indonesia \\ Elfiswandi² \\ University of Putra Indonesia YPTK Padang, Indonesia \\ Muhammad Ridwan ${ }^{3}$ \\ University of Putra Indonesia YPTK Padang, Indonesia
}

\begin{abstract}
The success or failure of an organization is determined by the human element who does the work, so that an employee needs to be treated well so that the employee remains passionate about work. Organizational leaders are required to treat employees well and view them as human beings who have needs, both material and non-material. Organizational leaders also need to know and try to meet the needs of employees, so that employees can work according to organizational expectations. This study aims to identify and analyze the efforts that can be made in order to increase employee morale because it needs to be empirically proven the factors that influence employee performance. In this study the number of samples used was 41 employees. The technique used in sampling is a census method that is based on questionnaire distribution, the data used is primary data. Data analysis method uses quantitative methods using Smart PLS.3 software. The results of testing the hypothesis found that Leadership Style has a significant effect on Employee Performance when mediated by high Employee Motivation so that the implications of this study are to improve leadership style in carrying out tasks and responsibilities in work such as fair, contribute positively and improve leadership training so that in making decisions more easily, and applying idealized influence, inspirational motivation, intellectual simulation and individualized consideration, the leadership style will also increase and have a positive effect on improving employee performance.
\end{abstract}

Keywords: Leadership Style, Work Motivation, Employee of Performance 


\section{International Conference on}

BUSINESS, MANAGEMENT \& ECONOMICS
$21-23$ D e c e m b e r , 2018

B e r $1 \mathrm{in}-\mathrm{G}$ e $\mathrm{rm}$ a $\mathrm{n}$ y

\section{Introduction}

High or low employee morale is influenced by many factors, some of which are such as employee awareness of organizational goals, human relations in the organization, leadership, organizational level, wages and salaries, opportunities for promotion, division of tasks, responsibilities, individual abilities, feelings accepted in groups, environmental dynamics and personality. Of these factors, one of the factors that influence work morale is leadership that is applied in the company.

The ability of leaders to influence and inspire others will provide their own motivation for employees to do something to achieve the desired goals, so that it will trigger the morale of these employees. Based on empirical research conducted (Alonderiene \& Majauskaite, 2016) shows the positive and significant impact of leadership style on job satisfaction that can improve employee performance, while the results of research (Hidayat, Rafiki, \& Aldoseri, 2017) explain that leadership styles are well applied in Bahrain government organizations are transactional leadership and transformational leadership, research (Haakonsson \& Burton, 2008) misalignment between organizational climate and leadership style has an impact on organizational performance, (Overstreet et al., 2013) explains that leadership style with organizational performance is good directly or indirectly shows a positive relationship where leaders motivate organizational change based on their peculiarities and perceptions of the environment, (Silverthorne \& Chen, 2012) the higher the leader's leadership score, the more effective the leader's influence.

Further research conducted by (Limsila \& Ogunlana, 2007) Transformational leadership style has a positive relationship with organizational performance and commitment, (Liu, 2013). Research conducted in companies in China shows that leadership change affects employee turnover which is moderated by collective human resources. while (Mohammad \& Rad, 2006) explains that there is a significant correlation between leadership behavior towards employees and job satisfaction such as participatory leader behavior, the results of the study (Pawirosumarto, Sarjana, \& Muchtar, 2017) show that there are positive and significant influences simultaneously between leadership style, work motivation, and discipline on employee performance. The results also show that there is a positive and partially significant influence between leadership style, employee motivation, and discipline on employee performance, (Limsila \& Ogunlana, 2007) 


\section{International Conference on}

BUSINESS, MANAGEMENT \& ECONOMICS

$21-23$ D e c e m b e r , 2018

B e r lin - G e r m a n y

Transformational leadership style has a positive relationship with employee performance and organizational commitment, research conducted on electronic companies Philips by (Peters, 2015) explains that the leadership style used by managers is different, (Shulhan, 2017) in leading schools, the principal must have an effective leadership style.

\section{Methods}

In this study the object of research is the performance of company employees in Indonesia. According to Sugiono (2003: 80) the population is a generalization area consisting of objects or subjects that have certain qualities and characteristics set by researchers to be studied and then drawn to conclusions. The population is the production department employees in the company. Samples can be defined as a part drawn from the population of Istijanto (2005: 115). Where to be able to obtain accurate data. The technique used in sampling is a random sampling method, which is as many as 41 employees of the company.

Primary data is data obtained from the first source both from individuals and group representatives. This data is the result of filling out questionnaires about work motivation and work environment filled by company employees. Secondary data is used to complete the data needed. Secondary data used in this study is in the form of data on the performance of production employees at the company. Data and information in this study are data sourced from the distribution of questionnaires that researchers spread to 41 company employees. To do data collection, the authors make data collection directly with field methods (field research), namely in the form of distributing questionnaires to company employees.

2.1 Data Analysis Techniques

\subsubsection{Model Specifications}

a. Convergent Validity Test uses outer loading parameters with rule of tumbs $>0.7$ and Average Variance Extracted (AVE) with rule of tumbs $>$ 0.5 and Communality with rule of tumbs $>0.5$

b. The discriminant validity test uses the parameters Average Variance Extracted (AVE) > latent variable correlation and cross loading with the rule of tumbs $>0.7$ in one variable

c. Reliability Test uses Cronbach Alpha parameters with rule of tumbs > 0.6 and Composite Reliability with rule of tumbs $>0.6$

\subsubsection{Model Evaluation}

Hypothesis testing is carried out if the Rule of tumbs from the support of a research hypothesis is: (1) if the coefficient or direction of the variable relationship (indicated by the original sample value) is in line 


\section{International Conference on \\ BUSINESS, MANAGEMENT \& ECONOMICS}

$21-23$ D e c e m b e r , 2018

B e r lin - G e r m a n y

with the hypothesis, and (2) if the t value is more than 1.64 (two -tiled) or 1.96 (one-tiled) and probability value ( $p$-value) less than 0.05 or $5 \%$.

Based on the study of theory and previous research, the framework of the study was made, namely in Figure 1. Following:

Figure:1. Framework

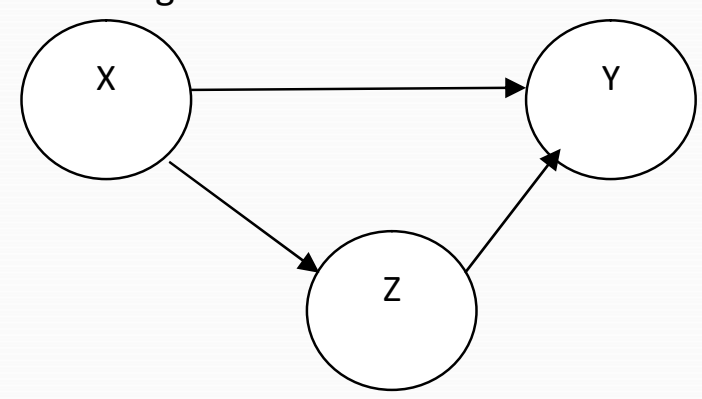

\section{Hypothesis:}

$\mathrm{H}_{1}$ : It is suspected that there is influence of Leadership Style $(X)$ on Employee Performance $(\mathrm{Y})$

$\mathrm{H}_{2}$ : It is suspected that there is an influence of Leadership Style $(X)$ on Employee Performance $(\mathrm{Y})$ mediated by Work Motivation ( $\mathrm{Z}$ ) 


\section{International Conference on}

BUSINESS, MANAGEMENT \& ECONOMICS
$21-23$ D e c e m b e r , 2018

B e r lin - G e r m a n y

\section{Results and Discussion}

\section{Description of Characteristics of Respondents}

From the results of questionnaires that have been conducted to 41 respondents in companies engaged in oil palm plantations, it can be seen that the characteristics of respondents in this study can be grouped by sex, age, years of service, marital status, employment status, education, departmental departments, and position employee. By knowing the identity of the respondent, the characteristics of the respondents will be seen in explaining variables well, in the form of leadership style variables as independent variables and work motivation as moderating variables and employee performance as the dependent variable in this study. For more details, they will be described one by one as follows:

1. Characteristics of Respondents by Gender

Data on the characteristics of respondents by sex can be seen in the table below:

Table 1.1

Characteristics Based on Gender

\begin{tabular}{|c|l|c|c|}
\hline No & \multicolumn{1}{|c|}{ Gender, } & Frequency & Percentage (\%) \\
\hline 1 & Male & 41 & $100 \%$ \\
\hline 2 & Female & - & - \\
\hline \multicolumn{2}{|c|}{ Jumlah } & $\mathbf{4 1}$ & $\mathbf{1 0 0 \%}$ \\
\hline
\end{tabular}

Source: Primer of Data, 2018 (process).

Based on Table 1.1 regarding the characteristics of respondents based on sex, it can be seen that respondents in this study were dominated by male respondents as many as 41 respondents with a percentage of $100 \%$. So it can be concluded that the distribution of characteristics of respondents by sex is dominated by male respondents, because the company is engaged in oil palm plantations that require a lot of male workers.

2. Age-Based Characteristics

Respondents by age can be seen in Table 1.2 below: 


\section{International Conference on}

\section{BUSINESS, MANAGEMENT \& ECONOMICS}

$21-23$ D e c e m b e r , 2018

B e r $1 \mathrm{in}-\mathrm{G}$ e $\mathrm{r} \mathrm{m}$ a $\mathrm{n} y$

Table 1.2

Characteristics of Respondents by Age

\begin{tabular}{|c|c|c|c|}
\hline No & Age & Total & Percentage (\%) \\
\hline 1 & $20-30$ years old & 22 & $53,65 \%$ \\
\hline 2 & $31-40$ years old & 14 & $34,15 \%$ \\
\hline 3 & $41-50$ years old & 5 & $12,20 \%$ \\
\hline \multicolumn{2}{|c|}{ Total } & $\mathbf{4 1}$ & $\mathbf{1 0 0 \%}$ \\
\hline \multicolumn{2}{|c|}{ Average } & 13,67 years \\
\end{tabular}

Source: Primer of Data, 2018 (process)

Based on Table 1.2 above regarding the characteristics of respondents based on age, where the highest respondents were those aged between 20-30 years as many as 22 respondents with a percentage of $53.65 \%$. Then followed by the age level of respondents between 31-40 years as many as 14 respondents with a percentage of $34.15 \%$. While the lowest respondents were those aged $41-50$ years as many as 5 respondents with a percentage of $12.20 \%$. Thus it can be concluded that the respondents of this study were dominated by employees aged between $20-30$ or with a percentage of $53.65 \%$. Because employees who are between the ages of 20-30 years are more needed because the company is engaged in a plantation that has many jobs in the field.

3. Characteristics Based on Work Period

Respondents based on employee tenure can be seen in Table 1.3 below:

Table 1.3

Characteristics of Respondents Based on Working Period

\begin{tabular}{|c|c|c|c|}
\hline No & Working Period & Total & Percentage (\%) \\
\hline 1 & 2-5 years & 13 & $31,71 \%$ \\
\hline 2 & $6-10$ years & 18 & $43,90 \%$ \\
\hline 3 & $11-15$ years & 5 & $12,19 \%$ \\
\hline 4 & $16-20$ years & 4 & $9,76 \%$ \\
\hline 5 & $>21$ years & 1 & $2,44 \%$ \\
\hline & Total & 41 & $100 \%$ \\
\hline & Average & \multicolumn{2}{|c|}{8,2 years } \\
\hline
\end{tabular}

Source: Primer of Data, 2018 (process) 


\section{International Conference on BUSINESS, MANAGEMENT \& ECONOMICS}

$21-23$ D e c e m b e r , 2018

B e r lin - G e r m a n y

Based on Table 1.3 regarding the characteristics of respondents based on years of service, from 41 respondents who were sampled in this study, respondents based on the largest employee tenure, namely with a working period of 6-10 years as many as 18 people or with a percentage of $43.90 \%$, the lowest employee work, with a working period of $>21$ years as many as 1 person or a percentage of $2.44 \%$. Thus it can be concluded that the study respondents were dominated by employees who worked from 6-10 years as many as 18 people or with a percentage of $43.90 \%$. Because most of the employees of this company, they started working from high school graduates.

4. Characteristics Based on Employee Wedding Status

Respondents based on the marital status of employees can be seen in Table 1.4 below:

Table 1.4

Characteristics of Respondents Based on Marriage Status

\begin{tabular}{|c|l|c|c|}
\hline No & Status & Total & Percentage (\%) \\
\hline 1 & Married & 31 & $76,60 \%$ \\
\hline 2 & Not Married & 10 & $24,39 \%$ \\
\hline \multicolumn{2}{|c|}{ Total } & $\mathbf{4 1}$ & $\mathbf{1 0 0 \%}$ \\
\hline
\end{tabular}

Source: Primer of Data, 2018 (process)

Based on Table 1.4 regarding the characteristics of respondents based on marital status, from 41 respondents who were sampled in this study, respondents based on the largest marital status of employees were married status as many as 31 people or at $76.60 \%$, while the lowest marital status Unmarried status as many as 10 people or with a percentage of $24.39 \%$. Thus it can be concluded that the study respondents were dominated by employees who were married as many as 31 people or with a percentage of $76.60 \%$. 


\section{International Conference on BUSINESS, MANAGEMENT \& ECONOMICS}

$21-23$ D e c e m b e r , 2018

B e r lin - G e r m a n y

5. Characteristics Based on Job Status

Respondents based on employee employment status can be seen in Table 1.5 below:

Table 1.5

Characteristics of Respondents Based on Job Status

\begin{tabular}{|c|l|c|c|}
\hline No & Status & Total & Percentage (\%) \\
\hline 1 & Training & 5 & $12,20 \%$ \\
\hline 2 & Contract & 16 & $39,02 \%$ \\
\hline 2 & Permanent & 20 & $48,78 \%$ \\
\hline \multicolumn{2}{|c|}{ Total } & $\mathbf{4 1}$ & $\mathbf{1 0 0 \%}$ \\
\hline
\end{tabular}

Source: Primer of Data, 2018 (process)

Based on table 1.5 above, it can be seen that the work of the research respondents was the highest, namely permanent employees as many as 20 respondents with a percentage of $48.78 \%$, then followed by contract employees as many as 16 people with a percentage of $39.02 \%$, while the least were employees training as many as 5 respondents with a percentage of $12.20 \%$.

6. Characteristics Based on Education

For the characteristics of respondents based on employee marital status can be seen in Table 1.6 below:

Table 1.6

Characteristics of Respondents by Education

\begin{tabular}{|c|l|c|c|}
\hline No & Education & Total & Percentage (\%) \\
\hline 1 & High school & 34 & $82,93 \%$ \\
\hline 2 & Bachelor & 7 & $17,07 \%$ \\
\hline \multicolumn{2}{|c|}{ Total } & $\mathbf{4 1}$ & $\mathbf{1 0 0 \%}$ \\
\hline
\end{tabular}

Source: Primer of Data, 2018 (process) 


\section{International Conference on BUSINESS, MANAGEMENT \& ECONOMICS}

$21-23$ D e c e m b e r , 2018

B e r lin - G e r m a n y

Based on Table 1.6 above can be seen the last educational characteristics of respondents, Of the 41 respondents who became the sample in this study, the most are respondents with high school / high school education as many as 34 respondents or with a percentage of $82.93 \%$. And the lowest level of education is respondents with $\mathrm{S} 1$ education as many as 7 respondents with a percentage of $17.07 \%$. Thus it can be concluded that the respondents of this study were dominated by employees with a high school / high school education level of 34 respondents with a percentage of $82.93 \%$.

7. Characteristics of Respondents by Department

For the characteristics of the respondents based on the department of employee department can be seen in Table 1.7 below:

Table 1.7

Characteristics of Respondents by Department

\begin{tabular}{|c|c|c|c|}
\hline No & Department & Total & Percentage (\%) \\
\hline 1 & Divisi 1 & 11 & $26,83 \%$ \\
\hline 2 & Divisi 2 & 6 & $14,63 \%$ \\
\hline 3 & Divisi 3 & 9 & $21,95 \%$ \\
\hline 4 & Divisi 4 & 8 & $19,52 \%$ \\
\hline 5 & Divisi 5 & 7 & $17,07 \%$ \\
\hline & Total & 41 & $100 \%$ \\
\hline
\end{tabular}

Source: Primer of Data, 2018 (process)

Considering Table 1.7 above, it can be concluded that the respondents were the most, namely in the division 1 division as many as 11 people or with a percentage of $26.83 \%$. Whereas the least number is in division 2 as many as 6 respondents or with a percentage of $14.63 \%$. 


\section{International Conference on}

BUSINESS, MANAGEMENT \& ECONOMICS

$21-23$ D e c e m b e r , 2018

B e r lin - G e r m a n y

8. Characteristics of Respondents by Position

For the characteristics of respondents based on the position of employees can be seen in Table 1.8 below:

Table 1.8

Characteristics of Respondents by Position

\begin{tabular}{|c|c|c|c|}
\hline No & Position & Frequency & Percentage (\%) \\
\hline 1 & Manajer & 1 & $2,44 \%$ \\
\hline 2 & Mandor & 1 & $2,44 \%$ \\
\hline 3 & Kepala Divisi & 1 & $2,44 \%$ \\
\hline 4 & Asisten & 1 & $2,44 \%$ \\
\hline 5 & Staff & 37 & $90,24 \%$ \\
\hline \multicolumn{2}{|r|}{ Total } & 41 & $100 \%$ \\
\hline
\end{tabular}

Source: Primer of Data, 2018 (process)

Based on Table 1.8 above, it can be concluded that the highest number of respondents is in the staff department as many as 34 respondents with a percentage of $90.24 \%$, while the least number is in the department manager, foreman, head of division, and assistant are 1 respondent with a percentage of $2.44 \%$.

3.2. Analysis Results by Smart PLS 3. (Partial Least Square)

\subsubsection{Goodness of Fit}

The Goodness of Fit model can be seen from the predictive relevance value $\left(Q^{2}\right)$ which is calculated based on $\mathrm{R}^{2}$ from each endogenous variable, the calculation results are 0.581 or $58.1 \%$ indicating that the diversity of data that can be explained by the smart PLS.3 model built is equal to $58.1 \%$ while the remaining $41.9 \%$ is explained by other variables and errors.

\subsubsection{Outer Model Results}

The Outer Model is a measurement of variables based on the indicators. The value of the outer loading or outer weight shows the weight of each indicator as a measure of each latent variable. The indicator with the largest outer loading or outer weight means that the indicator is a strong measure of the variable. 


\section{International Conference on}

\section{BUSINESS, MANAGEMENT \& ECONOMICS}

$21-23$ D e c e m b e r , 2018

B e r lin - G e r m a n y

\subsubsection{Leadership Style}

Leadership Style Has 4 (four) dimensions where each dimension has an indicator with a t-statistic value $<1.96$ and $p$-value $>0.05$ which indicates that the indicator is not significant in measuring the Leadership Style variable as explained in table.1.9.

Table 1.9.

Outer Model in the Leadership Style (X)

\begin{tabular}{|l|c|c|c|}
\hline \multicolumn{1}{|c|}{ Dimension and Indicators } & $\begin{array}{c}\text { Outer } \\
\text { Loading }\end{array}$ & t-statistik & p-value \\
\hline TOTX1 = Idealized Influence & 0,757 & 1,140 & 0,255 \\
X1 = The leader has authority & 0,854 & 1,166 & 0,244 \\
X2 = The leader is willing to sacrifice & 0,553 & 1,128 & 0,260 \\
X3 = The leader instills a vision and mission, & 0,260 & 0,723 & 0,470 \\
$\quad$ pride, and trust & & & \\
TOTX2 = Inspirational Motivation & $-0,468$ & 0,910 & 0,363 \\
X4 = The leader gives inspiration & $-0,429$ & 0,900 & 0,368 \\
X6 = The leader of a motivator & $-0,463$ & 0,911 & 0,363 \\
TOTX3 = Intellectual Simulation & $-0,692$ & 1,068 & 0,286 \\
X7 = Leaders encourage to think & $-0,498$ & 0,954 & 0,341 \\
X8 = The leader encourages to search & $-0,491$ & 1,010 & 0,313 \\
$\quad$ organizational problem solving & & & \\
X9 = Leaders encourage to think & $-0,657$ & 1,073 & 0,284 \\
$\quad$ before acting & $-0,639$ & 1,101 & 0,271 \\
TOTX4 = Individual Consideration & $-0,548$ & 1,041 & 0,298 \\
X10 = Leaders pay attention to availability $\quad$ facilities and infrastructure & & & \\
X11 = The leader hears complaints & $-0,456$ & 1,023 & 0,307 \\
$\quad$ every employee & & & \\
X12 = Leaders give awards & $-0,227$ & 0,772 & 0,441 \\
$\quad$ & & & \\
\hline
\end{tabular}

Source: Primer of Data, 2018 (process) 


\section{International Conference on}

\section{BUSINESS, MANAGEMENT \& ECONOMICS}

$21-23$ D e c e m b e r , 2018

B e r lin - G e r m a n y

\subsubsection{Work Motivation}

Has 3 (three) dimensions that have indicators with t-statistic values> 1.96 and $p$-value $<0.05$ except in indicators Glad if a colleague asks for help (Z7) it means that dimensions and indicators can be used to measure Motivation variables Work, can be seen in table.1.10.

Table 1.10.

Outer Model in Work Motivation (Z)

\begin{tabular}{|l|c|c|c|}
\hline \multicolumn{1}{|c|}{ Dimension and Indicator } & $\begin{array}{c}\text { Outer } \\
\text { Loading }\end{array}$ & t-statistik & p-value \\
\hline TOTZ1 = Needs to Achieve & 0,922 & 6,163 & 0,000 \\
Z1 = Work performance achieved & 0,774 & 4,996 & 0,000 \\
Z2 = Try various alternatives to reach & 0,867 & 5,333 & 0,000 \\
$\quad$ success at work & 0,577 & 3,555 & 0,000 \\
Z3 = Motivation to excel at work & 0,560 & 2,665 & 0,008 \\
Z4 = Competition in achieving achievements & 0,697 & 3,478 & 0,001 \\
TOTZ2 = Needs to be Affiliated & 0,715 & 4,697 & \\
Z5 = Work results are appreciated by the & & & \\
$\quad$ leadership and co-workers & 0,285 & 1,117 & 0,265 \\
Z7 = Glad if a colleague asks for help & 0,881 & 5,080 & 0,000 \\
TOTZ3 = Need for Strength & 0,485 & 2,076 & 0,038 \\
Z8 = Involved in decision making & 0,634 & 2,893 & 0,004 \\
Z9 = Give good instructions to & & & \\
$\quad$ co-workers & 0,755 & 5,173 & 0,000 \\
Z11 = Directing co-workers towards that & & & \\
$\quad$ better at work & 0,604 & 2,932 & 0,004 \\
Z13 = Challenged to ask for responsibility & & & \\
$\quad$ greater responsibility and authority & &
\end{tabular}

Source: Primer of Data, 2018 (process)

3.2.2.3. Employee of Performance 


\section{International Conference on}

\section{BUSINESS, MANAGEMENT \& ECONOMICS}

$21-23$ D e c e m b e r , 2018

B e r lin - G e r m a n y

Having 3 (three) dimensions, each dimension has an indicator in the first dimension along with its indicators having a t-statistic value> 1.96 and a $p$-value $<0.05$ also indicates that dimensions and indicators can still be used to measure employee performance variables although in the second and third dimensions and their indicators have t-statistics values $<1.96$ and nilau $p$-values $>0.05$, can be seen in table.1.11.

Table. 1.11.

Outer Model on Employee Performance (Y)

\begin{tabular}{|l|c|c|c|}
\hline \multicolumn{1}{|c|}{ Dimension adn Indicator } & $\begin{array}{c}\text { Outer } \\
\text { Loading }\end{array}$ & t-statistik & p-value \\
\hline TOTY1 = Employee Attendance Level & 0,901 & 4,406 & 0,000 \\
Y1 = Don't present to give news to leader & 0,667 & 3,588 & 0,000 \\
Y3 = Most in accordance with the rules of & & & \\
$\quad$ working hours & 0,560 & 2,627 & 0,000 \\
Y4 = Paying attention to order attendance & 0,732 & 3,042 & 0,002 \\
$\quad$ every day at work & 0,392 & 1,194 & 0,233 \\
TOTY2 = Low damage & 0,372 & 1,138 & 0,256 \\
Y5 = Do the work carefully & 0,689 & 3,032 & 0,003 \\
TOTY3 = No anxiety & 0,628 & 3,091 & 0,002 \\
Y7 = Establish good relations with colleagues & & & \\
$\quad$ other coworkers & 0,104 & 0,436 & 0,663 \\
Y8 = Establish good relations with leader & 0,565 & 2,295 & 0,022 \\
Y9 = Feeling at work & & & \\
\hline
\end{tabular}

Source: Primer of Data, 2018 (process)

\subsubsection{Inner Model Results}

Inner model testing or structural model essentially tests the relationship between variables in the study. Hypothesis testing is carried out with t-statistics and $p$-values for each influence path partially, as described in table.1.12. 


\section{International Conference on \\ BUSINESS, MANAGEMENT \& ECONOMICS}

$21-23$ D e c e m b e r , 2018

B e r lin - G e r m a n y

\subsubsection{Direct Influence}

Direct influence is the effect directly measured from one variable to another without any intervening variable, this direct variable is the Leadership Style (X) for Employee Performance $(\mathrm{Y})$ as described in table.1.12. below because the value of t-statistic is $<1.96$ and the value of $p$-value $>0.05$, there is no direct influence between Leadership Style $(\mathrm{X})$ on Employee Performance $(\mathrm{Y})$, as described in table 1.12.

Table.1.12.

The Results for Direct Influence in the Inner Model

\begin{tabular}{|c|c|c|c|c|}
\hline Direct & Inner Weight & t-statistik & $p$-value & Conclusion \\
\hline $\mathrm{X} \rightarrow \mathrm{Y}$ & 0,405 & 1,000 & 0,318 & Non-Signifikan \\
\hline
\end{tabular}

ource: Primer of Data, 2018 (process)

3.2.3.2. Indirect Influence

Indirect influence is the effect that is measured indirectly between variables mediated by intervening variables, the coefficient of indirect influence is obtained from the multiplication of each direct influence variable, as described in table.1.13. below this.

Table.1.13.

The Results for Indirect Effects in the Inner Model

\begin{tabular}{|c|c|c|c|}
\hline $\begin{array}{c}\text { Direct } \\
\text { Influence 1 }\end{array}$ & $\begin{array}{c}\text { Direct Influence } \\
2\end{array}$ & $\begin{array}{c}\text { Indirect } \\
\text { Influence }\end{array}$ & Conclusion \\
\hline $\begin{array}{c}\mathrm{X} \rightarrow \mathrm{Z} \\
\text { Koef: 0,544 }\end{array}$ & $\begin{array}{c}\mathrm{Z} \rightarrow \mathrm{Y} \\
\text { Koef: } 0,570 \\
\text { Signifikan }\end{array}$ & $\begin{array}{c}\mathrm{X} \rightarrow \mathrm{Y} \text { by } \\
\text { mediation } \mathrm{Z} \\
\text { Koef: } 0,544 \mathrm{X} \\
0,570=0,31008\end{array}$ & $\begin{array}{c}\text { The indirect effect of } \mathrm{X} \text { on } \mathrm{Y} \\
\text { mediated by Z is Non-Significant }\end{array}$ \\
\end{tabular}

Source: Primer of Data, 2018 (process) 


\section{International Conference on BUSINESS, MANAGEMENT \& ECONOMICS}

$21-23$ D e c e m b e r , 2018

B e r lin - G e r m a n y

\subsubsection{Hypothesis testing}

H1: Leadership Style has an influence on Employee Performance

Based on the results of testing the direct effect there is no influence of the Leadership Style on Employee Performance thus this Hypothesis 1 is rejected.

H2: Leadership Style has an influence on Employee Performance mediated by Work Motivation

Based on the results of testing the indirect effect there is no effect of Leadership Style on Employee Performance mediated by Work Motivation thus Hypothesis 2 is also rejected.

3.2.3.4. Measuring Every Variable

3.2.3.4.1. Measurement of Leadership Style variables

The most powerful indicator as a measure of Leadership Style is an authoritative leader who is influenced by a leader who has an idial influence with the value of outer loading 0.854 with the highest indicator. This finding means that leaders who can improve employee performance are authoritative leaders.

\subsection{Measurement of Work Motivation variables}

The most powerful indicator as a measure of Employee Motivation is an employee who can try various alternatives to achieve success in work that is influenced by the desire of employees to achieve with the value of outer loading 0.867 with the highest indicator. This finding means that those who can improve employee performance are employees who want to try various alternatives to achieve success at work.

\subsection{Measurement of Employee Performance variables}

The most powerful indicator as a measure of Employee Performance is employees who always pay attention to the orderly level of daily attendance at work which is influenced by the level of attendance of employees in working with the value of outer loading 0.732 with the highest indicator. This finding means that those who can improve employee performance are employees who have a good level of attendance at work. 


\section{International Conference on}

BUSINESS, MANAGEMENT \& ECONOMICS
$21-23$ D e c e m b e r , 2018

B e r lin - G e r m a n y

\section{Conclusion}

The conclusions in this study are (1). Leadership style owned by leaders directly has not been able to improve employee performance. (2). Leadership style that is owned by the leader indirectly has been able to improve employee performance even though it is not yet fully mediated by good work motivation.

\section{Acknowledgements}

The researcher presents his sincere appreciation goes to President of YPTK Padang and Rector University of Putra Indonesia "YPTK" Padang for its support to this reasearch and this research Grant Number: 010/UPI-YPTK/R/VII/2018

\section{References}

- Alonderiene, R., \& Majauskaite, M. (2016). Leadership style and job satisfaction in higher education institutions. https://doi.org/10.1108/IJEM-08-2014-0106

- Haakonsson, D. D., \& Burton, R. M. (2008). How failure to align organizational climate and leadership style affects performance. https://doi.org/10.1108/00251740810863861

- Hidayat, S. E., Rafiki, A., \& Aldoseri, M. M. (2017). Application of leadership style in government organizations : a survey in the Kingdom of Bahrain. https://doi.org/10.1108/IMEFM-06-2015-0075

- Istijanto. 2005. Riset Sumber Daya Manusia, Gramedia Pustaka Utama: Jakarta.

- Limsila, K., \& Ogunlana, S. O. (2007). Performance and leadership outcome correlates of leadership styles and subordinate commitment. https://doi.org/10.1108/09699980810852682

- Liu, Z. (2013). Leadership style and employee turnover intentions : a social identity perspective, 18(3), 305-324. https://doi.org/10.1108/CDI-09-2012-0087

- Mohammad, A., \& Rad, M. (2006). A study of relationship between managers' leadership style and employees ' job satisfaction, 19(2).

https://doi.org/10.1108/13660750610665008

- Overstreet, R. E., Hanna, J. B., Byrd, T. A., Cegielski, C. G., Hazen, B. T., Overstreet, R. E., ... Hazen, B. T. (2013). Leadership style and organizational innovativeness drive motor carriers toward sustained performance. https://doi.org/10.1108/IJLM-12-2012-0141

- Pawirosumarto, S., Sarjana, P. K., \& Muchtar, M. (2017). Article information : https://doi.org/10.1108/IJLMA-03-2016-0031 


\section{International Conference on BUSINESS, MANAGEMENT \& ECONOMICS}

$21-23$ D e ce m b e r , 2018 B e r lin - G e r m a n y

- Peters, R. (2015). Leadership style and entrepreneurial change The Centurion operation at Philips. https://doi.org/10.1108/09534810910933915

- Shulhan, M. (2017). Leadership style in the Madrasah in Tulungagung: how principals enhanced teacher performance.

- Silverthorne, J. C. C., \& Chen, J. (2012). Leadership effectiveness, leadership style and employee readiness. https://doi.org/10.1108/01437730510600652

- Sugiono. 2003. Statistik Untuk Penelitian (cetakan kelima). CV: Bandung. 